\title{
Economic consequences of alternative stocking rate adjust- ment tactics: a simulation approach
}

\author{
R.K. RIECHERS, J.R. CONNER, AND R.K. HEITSCHMIDT
}

\begin{abstract}
An economic analysis of alternative stocking rate adjustment tactics is performed using a simulation model which emulates the annual deciaion-making situation of a rancher. The model includes variation in livestock prices and annual forage production. The manager's decisions are based on the availability of forage at 4 decision points in the year, the expected growth between the current decision point and the next, and the expected portion of the forage that is to be harvested through graxing. Livestock are bought and sold to adjust the stocking rate to equal the expected available forage for grazing. Results are obtained for 3 different stocking tactics based on 4 levels of expected forage production and livestock utilization set at the May decision point. The results reflect the differences in net returns over variable costs and the differences in annual cow investment capital associated with each tactic. The results indicate that the tactics using a maximum stocking rate of $3.6 \mathrm{ha} / \mathrm{au}$ offer the most ressonable compromise between mean and variance of net returns. The tactic with no limit on stocking rate provides the possibility of obtaining higher average annual net returms than trectics with limited stocking rates, but the variation in annual returns is considerably greater and the annual cow investments costs are higher.
\end{abstract}

Key Words: cow/calf production, net returns, simulation model

Cattle producers face 2 principal sources of uncertainty: prices and weather. The rancher must manage within the constraints of these uncertainties while trying to meet the production, marketing, and financial objectives of the firm.

Grazing management is a tool used to meet ranch firm objectives. Grazing management, broadly defined, is the manipulation of grazing animals to achieve desired results (Society for Range Management 1974). Although various grazing management strategies may be implemented to alter the temporal and spatial distribution of various kinds or classes of grazing animals, the major decision affecting level of production achieved is stocking rate. Through the timely adjustment of stocking rate, management can effectively buffer the adverse effects of uncertainty relative to forage availability and livestock prices. The ability to adjust may

\footnotetext{
Authors are economist, Texas Parks and Wildlife Department, Austin 78744; professor, Department of Agricultural Economics, Texas A\&M University, College Station, 77843; and professor, Texas Agricultural Experiment Station, Vernon, 76384 .

Manuscript approved by the Director, Texas Agricultural Experiment Station as TA-24012

Manuscript accepted 22 September 1988.
}

help the firm survive the occurrence of an undesirable event, such as drought, and may thus decrease the risk of an undesirable outcome. The objective of this study was to develop and illustrate the use of a simulation model to analyze the economic implications to a ranch business of using alternative decision rules (tactics) to adjust stocking rate in accordance with annual fluctuations in forage availability.

Several approaches have been used in the past to determine the economic consequences of stocking rate decisions made by producers. Halter and Dean (1965) used Bayesian decision theory in a pay off table framework to analyze the consequences of alternative stocking rates in the foothills of California. Whitson (1974) used simple and multiperiod quadratic programming to model a representative ranch and derive sets of efficient income variance plans, while simultaneously incorporating time and uncertainty into the firm manager's decision environment.

In this study, simulation offers a way to assess long-term effects of alternative tactics for adjusting stocking rate in accordance with variations in forage production and to simultaneously include the impacts of variations in cattle prices on the outcome. Simulation allows the results of the alternative tactics to be monitored through time to determine which tactics create the greatest variance in cattle numbers and how these changes impact the mean and variance of net returns to the rancher's capital, land, and management.

\section{Materials and Methods}

\section{Study Area}

Data for this study were collected at the 2,900-ha Texas Experimental Ranch located in Throckmorton County. Climate in the area is highly variable with warm, wet springs and falls, hot summers, and mild winters. Average annual precipitation is 682 $\mathrm{mm}$. The frost free growing season averages 233 days and exends from March to November.

The principal range sites on the ranch are clay loam, clayey upland, clay slopes, and bottomland. The herbaceous vegetation is a mixture of mid and shortgrasses. Dominant perennial species are sideoats grama [Bouteloua curtipendula (Mixnx.) Torr.], a warmseason midgrass, buffalograss [Buchloe dactylotdes (Nutt.) Engelm.], a warm-season shortgrass, and Texas wintergrass [Stipa leucotricha Trin. and Rupr.], a cool-season midgrass. Japanese brome (Bromus japonicus Thunb.) is the dominant annual grass. For a detailed description of the study site see Heitschmidt et al. (1985). 


\section{Model Development}

The decision making environment of the ranch firm manager is, to a large degree, the result of weather-induced fluctuation in forage production and the strategies, tactics, and practices set by the manager. Management of grazing involves in part the estimation of the forage that will be available between 2 points in time (decision points) and the setting of a stocking rate that will allow the available forage to be economically utilized by his grazing animals. Thus, if the manager can reasonably estimate the forage that will be available between decision points and the amount that can be captured through livestock grazing, he can determine the stocking rate adjustments needed to efficiently utilize the forage available.

The model was designed (Fig. 1) to project a cow/calf ranching firm's cattle investment capital requirements and net returns over variable costs over time. Projections were based on costs and returns from weaned calf sales, as affected by adjustments in stocking rate and supplemental feeding practices coupled with random variations in product prices.

Decision points were 15 March, 30 May, 30 August, and 31 October. All decisions were based on amount of graminoid standing crop present. The 15 March decision concerned the date that feeding of winter supplement would be terminated (15 March vs. $30 \mathrm{March}$ ). All other decisions centered on stocking rate adjustments near the time of peak live standing crop ( 30 May), near the end of the period of summer dormancy (30 August), and near the end of the growing season (31 October). Decision rules regarding stocking rate adjustments and production variables and penalties were determined based on forage and livestock production data from the ranch.

Livestock production variables were followed through time to present a revenue figure based on yearly calf sales. Total variable costs were obtained annually, so annual net returns over variable costs could be calculated. Since stocking rate adjustments change the number of breeding cattle on a ranch at any point in time, annual changes in cow transactions above normal culling provide an indication of the costs associated with the buying and selling of cows for each alternative tactic. To allow comparison over time without inflationary influences, prices for all classes of livestock were adjusted using the producer price index to equal 1984 dollars. Therefore, both the net returns and the losses and gains in cow investment capital resulting from cow transactions above the normal culling rate are presented in 1984 dollars.

\section{Forage Standing Crop}

Forage standing crop on each of the 4 dates was predicted using 36-years of weather data from Throckmorton (USDC 1950-1985) and linear models that were developed using climatic and standing crop variables during the period from 1981 through 1984. The standing crop data were collected on a clay loam site in a 16paddock, 1-herd rotational grazing treatment stocked at a heavy rate (Heitschmidt et al. 1987a). The linear models were developed by examining correlation coefficients between various variables and reported standing crops at the 4 decision times in the year, and by examining the correlation coefficients between standing crops within a year. The final equations selected were:

$$
\begin{gathered}
\mathrm{SC} 1=152.566+98.342 \mathrm{X}_{1}+216.193 \mathrm{X}_{2} \\
\mathrm{R}^{2}=0.688 \mathrm{df}=11 \\
\mathrm{SC} 2=42.912+175.04 \mathrm{X}_{3}+.4509 \mathrm{SCl} \\
\mathrm{R}^{2}=0.851 \mathrm{df}=11 \\
\mathrm{SC} 3=599.889+30.141 \mathrm{X}_{4} \\
\mathrm{R}^{2}=0.656 \mathrm{df}=11 \\
\mathrm{SC} 4=-349.268=31.353 \mathrm{X}_{6}+0.891 \mathrm{SC} 3 \\
\mathrm{R}^{2}=0.597 \mathrm{df}=12
\end{gathered}
$$

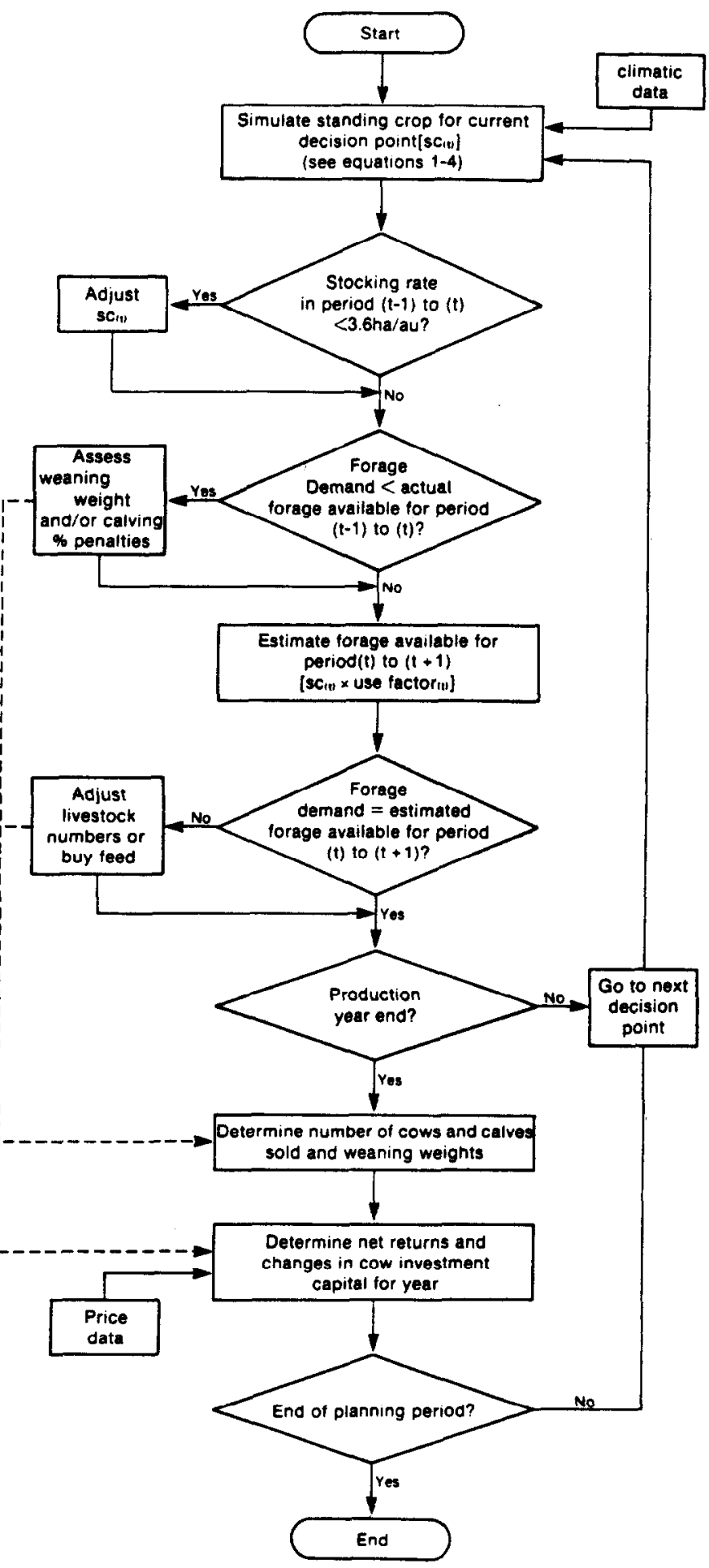

Fig. 1. A flow diagram of the model.

where:

SCl = graminoid standing crop ( $\mathrm{kg} / \mathrm{ha}$ ) for 15 March.

SC2 = graminoid standing crop (kg/ha) for 30 May.

SC3 = graminoid standing crop ( $\mathrm{kg} / \mathrm{ha}$ ) for August 30 .

SC4 = graminoid standing crop $(\mathrm{kg} / \mathrm{ha})$ for 31 October.

$X_{1} \quad=$ total rainfall (cm) for Jan., Feb., and Mar.

$\mathbf{X}_{2} \quad$ average minimum temperature (c) in Feb.

$\mathbf{X}_{\mathbf{3}} \quad=$ total rainfall $(\mathrm{cm})$ for Mar. and Apr.

$X_{\mathbf{A}}=$ total rainfall $(\mathrm{cm})$ for May and June.

$\mathrm{X}_{\mathrm{b}}$. $=$ total rainfall $(\mathrm{cm})$ for Sept. and Aug. 
Predicted standing crops at time $t$ were adjusted to reflect the effects of different rates of stocking from time $t-1$ to time $t$. For the purposes of this study it was assumed the effects of stocking rate were directly proportional to forage demand as demonstrated by Heitschmidt et al. (1987a). In general, adjustments were made based on forage demand/animal unit estimates as reported by Olson (1984). Estimates were based on previously published (Heitschmidt et al. 1987) and unpublished cow and calf weights and forage organic dry matter digestibility estimates at the ranch (Heitschmidt et al. 1987b). For the purposes of the model, organic dry matter intake/cow was set at 13.66, 13.15, 11.65, and 9.63 $\mathrm{kg} / \mathrm{da}$ for the periods between 15 March and 30 May, 30 May and 30 August, 30 August and 31 October, and 31 October and 15 March, respectively. Estimated intake/calf was set at $4.92 \mathrm{~kg} / \mathrm{da}$ for the period from 30 August to 31 October. Intake/calf prior to 30 August was assumed to be negligible.

For the model to satisfactorily meet the objectives of this study, an estimate of the amount of forage available for consumption between 2 decision points was required to establish decision rules. Although considerable effort was expended in an attempt to model the varied biological processes that would affect standing crop at any given decision point (senescence, trampling, herbivore, etc.), it became apparent during the process that this was not necessary (Riechers 1986). We reasoned that producers make most stocking rate decisions based upon amount of standing crop present at a given time and his/ her perception of amount of standing crop that will be present at some future time. Moreover, we recognized that with yearlong grazing regimes, such as cow/calf operations, most stocking rate decisions made prior to the end of the growing season are influenced by that producer's perception of what the standing crop will be at the beginning of the next growing season. In other words, the decision to adjust rate of stocking in late June is influenced by the producer's perception of not only its impact on standing crop in late August and October, but also its potential
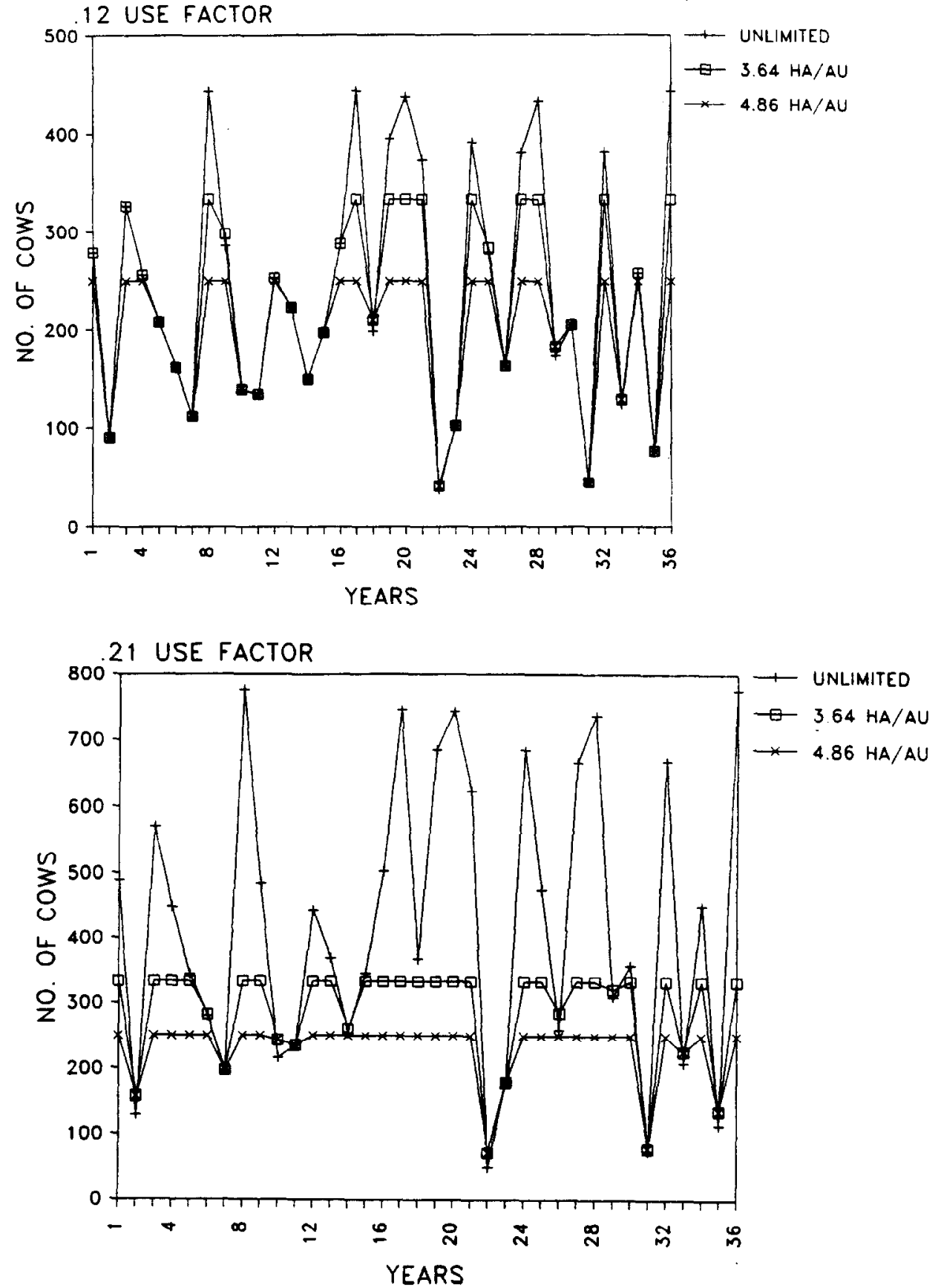

Fig. 2. Cow numbers on the ranch after the May decision point for the 3 tactics at 2 use factors. 
impact on standing crop the next spring.

To effectively model these considerations into the decision making process, we began by again examining the standing crop data from the heavily stocked rotational grazing treatment from which the standing crop predictive equations were derived. Because stocking rate in this treatment was high, available standing crop at the end of the winter dormancy periods from 1982 through 1984 was usually perceived to be near zero relative to a cow's ability to harvest the residue. Average graminoid standing crops across the 3 years were about $775,1,250,1,250$, and $950 \mathrm{~kg} /$ ha on 15 March, 30 May, 30 August, and 31 October, respectively (Heitschmidt et al. 1987a). We then assumed net standing crop losses between decision points were equal to the forage demand of the grazing animals as shown to be true on an annual basis by Heitschmidt et al. (1987a). Estimated disappearance/forage demand values averaged about $250,300,250$, and $325 \mathrm{~kg} /$ ha across the 3 years for the periods from 15 March to 30 May, 30 May to 30 August, 30 August to 31 October, 31 October to 15 March, respectively.

The forage disappearance values between times $t$ and $t+1$ were then divided by the standing crop estimate at time $t$. These values for the 3 years averaged $0.32,0.24,0.20$, and 0.34 , respectively, for the periods beginning on 15 March, 30 May, 30 August, and 31 October. We then ran a series of simulations using these values to estimate the maximum amount of forage available for consumption between 2 decision points. Based on the output from these simulations, we adjusted these "use factor" estimates as necessary to develop an acceptable level of realism in the model. Final use factors selected were $0.25,0.50$, and 0.70 , respectively, for the March, August, and October decision points. Four use factors were used for the May decision point because the model was found to be quite sensitive to use factors at this critical decision point. Use factors for May were $0.12,0.15,0.18$, and 0.21 .

It should be emphasized that the inclusion of use factors in the model was required to establish realistic decision rules at each decision point. They did not affect estimates of amount of standing crop present at the next decision point if rate of stocking remained unchanged. They simply limited the magnitude of any upward adjustment in stocking rate. For a more detailed description concerning standing crop estimation procedures, see Riechers (1986).

\section{Livestock Production}

Estimates of the livestock production parameters used in the model (production/au and production/ha) were based on research reported by Heitschmidt et al. (1987c). Normal weaning weights for both August and October were set at 220.2 and $252.4 \mathrm{~kg}$, respectively. The 90-day breeding season began 1 April, and a weaning percentage of 80 was used under normal circumstances. The model, however, incorporated $4.5 \mathrm{~kg}$ reductions in weaning weights for each period when forage availability was less than demand based on the number of cattle actually present during the period. The model also incorporated a $3 \%$ reduction in weaning percentages when forage shortages were encountered during the October-March, and March-May periods reflecting the impact of cow condition at the beginning of the breeding season. Alternatively, if cow numbers were reduced in June, the weaning percent was increased by $5 \%$ since most of the cows sold in June would be those without calves.

\section{Costs and Prices}

Prices of inputs and outputs are another source of uncertainty facing the management of agricultural firms. Changes in prices have a direct impact on the net revenues and cash flows at the firm level. The inclusion of variations in both prices and standing crop insured the integrated effect of sources of uncertainty on the financial condition of a cow-calf firm could be addressed in the simulations.

Standard variable cost budgets were developed based on production estimates from 4 grazing treatments at the ranch (Conner and Chamberlain 1985). Normal net replacement costs for females, based on a 333 head base herd, a $2 \%$ death loss, and an $11 \%$ culling rate were included in the annual variable cost budgets. The annual variable net replacement cost per cow was calculated by subtracting the average cost of replacements from the yearly revenue obtained through the selling of cull cows. The viable net replacement cost of replacements was set a $\$ 15.03$ per cow based on the above assumptions. This permitted the cost differences associated with the alternative decision rules to be more accurately reflected in annual net returns and annual changes in cow investment capital.

The variable cost budgets also reflected the cost of purchasing

\section{NET RETURNS}

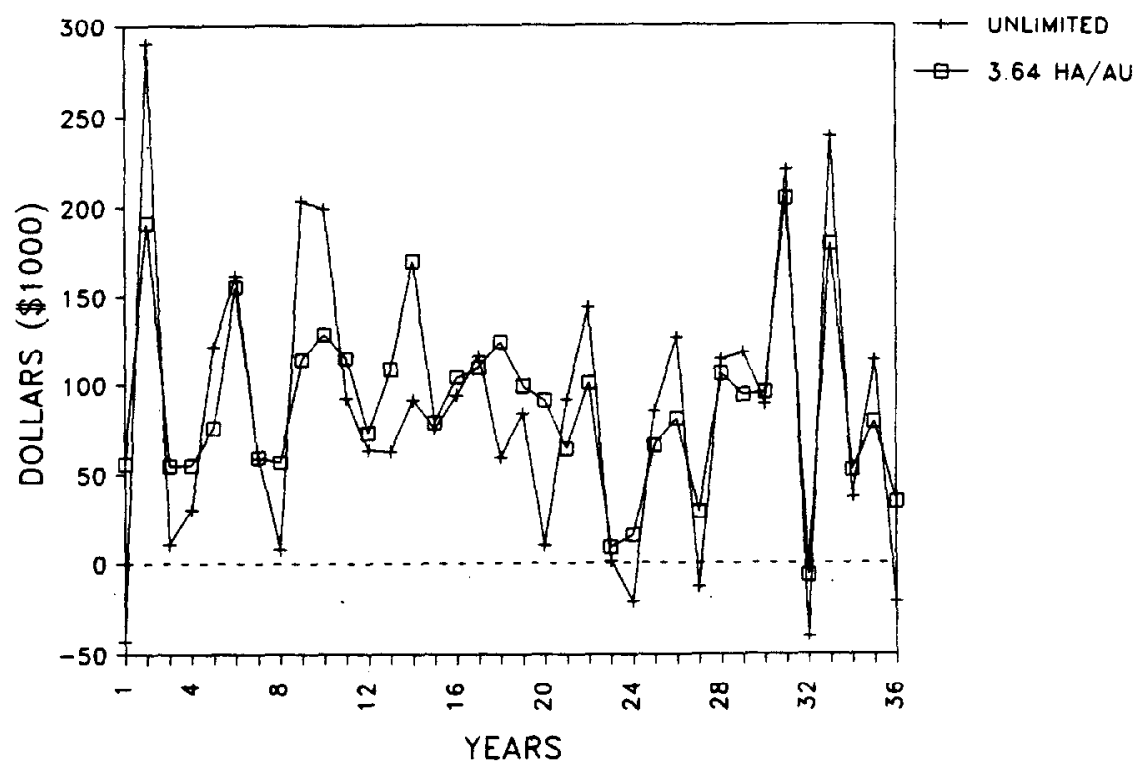

Fig. 3. Annual net retums over variable costs for unlimited and 3.6 ha/au stocking tactics at the 0.21 use factor over the 36 year period (1950-1985). 
and feeding when forage conditions warranted such feeding based on internal decision rules in the model. The additional costs were based on the number of cows kept through the winter and the number of days the animals were fed. It was assumed that each cow would be fed a $20 \%$ CP range cube at a rate of $1.36 \mathrm{~kg}$ /day for 90 days with the option to supplement for 15 extra days made at the March decision point if specified forage conditions were encountered. The cost of supplement was set at $\$ 0.24 / \mathbf{k g}$. (Conner and Chamberlain 1985). Without the 15 days of supplemental feeding the variable cost per cow was \$88.57. Each year the model calculated total variable cost by multiplying the variable cost per cow times the number of cows on the ranch after the May decision point.

Under the modeled setting, all calves were sold through an auction market either in August or October. Weaned steer prices were randomly drawn from average August steer prices at the Amarillo market from 1960 through 1980 . Annual prices for steers sold in months other than August and for the other classes of animal sold in August and other months were derived either through linear correlation or through the use of average price differences compared to August. If the correlation between the August steer prices and the price of the class in question was not significant $(P<0.05)$, an average price difference between the August steer price and the class based on the 20 years of price data was used to calculate the price for the class at any point in time.

The model allowed sales above normal culling to occur at the May, August, or October decision points. These transactions reflected the need to alter stocking rates in order to balance perceived forage availability with demand as mediated by the alternative decision rules. The model allowed livestock purchases to occur only at the May decision point. Cows purchased to capture available forage were assumed to weigh $454 \mathrm{~kg}$ and were bought at the cow price generated for the May decision point plus a standard $\$ 10$ per head marketing charge.

\section{Simulations}

The economic consequences of 3 different stocking rate tactics were simulated on a total land area of $1,215 \mathrm{ha}$. The first tactic set stocking rate at a maximum limit of $4.9 \mathrm{ha} / \mathrm{au}(250 \mathrm{head})$. The second tactic set the maximum limit of $3.6 \mathrm{ha} / \mathrm{au},(333 \mathrm{head})$ and no maximum was set in the third tactic. No minimum levels were set for any of the simulated tactics. The simulation of the third tactic began at a stocking rate of $3.6 \mathrm{ha} / \mathrm{au}$, since that was the base stocking rate used in the grazing treatment from which the forage data were derived. Results were contrasted between the 3 tactics and within the 3 tactics for the 4 May use factors.

\section{Results and Discussion}

With the unlimited stocking tactic, the maximum number of cows reached 776 head when the May use factor of 0.21 was used, 665 cows when the 0.18 use factor was used, 554 cows when the 0.15 use factor was used, and $\mathbf{4 4 3}$ cows with the 0.12 factor was used (Fig. 2). The lowest cow numbers at any point in time also occurred using the unlimited stocking rate tactic: When the 0.15 use factor was used for the May decision the cow herd reached a low of $\mathbf{3 6}$ head as compared to 37,41 , and 49 cows when the $0.12,0.18$, and 0.21 use factors were used, respectively. The lowest cow numbers for the 2 limited tactics were $41,51,62$, and 72 for the $0.12,0.15$, 0.17 , and 0.21 May use factors, respectively. The difference in cow numbers for the 3 tactics at both the lowest and highest use factors indicates the response to available forage.

The simulations showed that the unlimited stocking tactic required winter supplement be fed an additional 15 days (16-30 March) $34 \%$ of the time as compared to $30 \%$ of the time for the 2 limited strategies. The option to wean calves early (August) was not invoked over the 36-year period for the 2 limited tactics under any of the May use factors. However, the unlimited tactic invoked the penalty $3 \%$ of the years at the 2 lowest use factors and $19 \%$ and $27 \%$ of the years at the 0.18 and 0.21 May use factors, respectively. The weaning weight reduction was encountered in about $25 \%$ of the years for all tactics.

The average annual net returns over variable costs for each tactic are presented in Table 1. Average net returns for all May use

Table 1. Means, standard deviations, and the coefficient of variation for the net returns over variable costs over the 36 year period (1950-1985), based on different stocking rate tactics and use factors in May.

\begin{tabular}{|c|c|c|c|c|}
\hline \multirow[t]{2}{*}{$\begin{array}{l}\text { May Use } \\
\text { Factor }\end{array}$} & Stocking tactic & Mean & $\begin{array}{l}\text { Std } \\
\text { Dev }\end{array}$ & \multirow[b]{3}{*}{$\begin{array}{l}.61 \\
.68 \\
.77\end{array}$} \\
\hline & \multirow[b]{2}{*}{$\begin{array}{l}\text { Max. } 4.9 \mathrm{ha} / \mathrm{au} \\
\text { Max. } 3.6 \mathrm{ha} / \mathrm{au} \\
\text { Unlimited }\end{array}$} & $\square$ & & \\
\hline 0.12 & & $\begin{array}{l}61,469.18 \\
70,743.96 \\
75,889.02\end{array}$ & $\begin{array}{l}37,768.77 \\
48,370.81 \\
58,688.05\end{array}$ & \\
\hline 0.15 & $\begin{array}{l}\text { Max. } 4.9 \mathrm{ha} / \mathrm{au} \\
\text { Max. } 3.6 \mathrm{ha} / \mathrm{au} \\
\text { Unlimited }\end{array}$ & $\begin{array}{l}66,373.85 \\
79,491.20 \\
88,692.81\end{array}$ & $\begin{array}{l}37,330.38 \\
50,583.41 \\
67,817.71\end{array}$ & $\begin{array}{l}.56 \\
.64 \\
.76\end{array}$ \\
\hline 0.18 & $\begin{array}{l}\text { Max. } 4.9 \mathrm{ha} / \mathrm{au} \\
\text { Max. } 3.6 \mathrm{ha} / \mathrm{au} \\
\text { Unlimited }\end{array}$ & $\begin{array}{l}69,279.42 \\
85,742.09 \\
93,186.67\end{array}$ & $\begin{array}{l}35,057.98 \\
50,808.58 \\
71,388.02\end{array}$ & $\begin{array}{l}.51 \\
.59 \\
.77\end{array}$ \\
\hline 0.21 & $\begin{array}{l}\text { Max. } 4.9 \mathrm{ha} / \mathrm{au} \\
\text { Max. } 3.6 \mathrm{ha} / \mathrm{au} \\
\text { Unlimited }\end{array}$ & $\begin{array}{l}71,011.11 \\
89,481.06 \\
95,555.16\end{array}$ & $\begin{array}{l}33,323.96 \\
49,185.59 \\
78,621.48\end{array}$ & $\begin{array}{l}.47 \\
.55 \\
.82\end{array}$ \\
\hline
\end{tabular}

factors increased as the maximum allowable stocking rate increased. When the maximum stocking rate was changed from $4.9 \mathrm{ha} / \mathrm{au}$ to $3.6 \mathrm{ha} / \mathrm{au}$, annual net returns increased an average of $21 \%$ and relative variation increased $8 \%$. Comparing the differences between the $3.6 \mathrm{ha} / \mathrm{au}$ tactics and the unlimited stocking tactic annual returns averaged across all use factors, increased an average of $9 \%$ and variation increased an average of $15 \%$. Figure 3 depicts the annual variation between these 2 tactics over the 36-year period relative to net returns over variable costs.

The effects of May use factors on net returns varied among tactics. Annual net returns increased and coefficients of variation (relative variation in net returns) decreased continuously for both limited stocking tactics as the May use factor was increased from 0.12 to 0.21 . However, for the unlimited stocking rate tactic, average annual net returns increased and relative variation remained constant as the May use factor was increased from 0.12 to 0.18 . As the use factor was increased from 0.18 to 0.21 , however, average annual net returns increased $3 \%$ and relative variation increased $5 \%$.

The probabilities of net returns falling below $\$ 27,000.00 /$ year $(\$ 22.22 / \mathrm{ha})$ for 1 or more years and 3 or more years in any given 10-year period are presented in Table 2 . The threshold value of $\$ 27,000.00$ represents the minimum net returns required to meet the rancher's living expenses and service debts. This is slightly less than the annual ownership costs for the ranch as shown by Conner and Chamberlain (1985). The probabilities of net returns falling below the critical level were based on 27 ten-year periods obtained by grouping the 36 years of primary results. Years 1-10 were grouped then years 2-11, etc., until the group with years 27-36 was reached.

The net returns under any of the stocking tactics or any of the May use factors never fell below the critical level 5 or more years out of any 10-year period. Averaged across all of the May use factors, there was little difference between the $4.9 \mathrm{ha} / \mathrm{au}$ and 3.6 ha/au tactics in terms of the probability that annual income would fall below the threshold level in at least 1 or 3 years out of every 10 
Table 2. Probability that in any 10 year perlod net returns over variable cows will fall below $\$ 27,000$ in 1 and 3 or more years for 3 stocking tactica and 4 May ure factors.

\begin{tabular}{|c|c|c|c|}
\hline \multirow[b]{2}{*}{ May use factor } & \multirow[b]{2}{*}{ Stocking tactic } & \multicolumn{2}{|c|}{ Number of years in ten } \\
\hline & & One & Three \\
\hline & & & \\
\hline 0.12 & $\begin{array}{l}\text { Max. } 4.9 \mathrm{ha} / \mathrm{au} \\
\text { Max. } 3.6 \mathrm{ha} / \mathrm{au} \\
\text { Unlimited }\end{array}$ & $\begin{array}{l}81.5 \\
74.0 \\
81.5\end{array}$ & $\begin{array}{l}40.7 \\
37.0 \\
37.0\end{array}$ \\
\hline 0.15 & $\begin{array}{l}\text { Max. } 4.9 \mathrm{ha} / \mathrm{au} \\
\text { Max. } 3.6 \mathrm{ha} / \mathrm{au} \\
\text { Unlimited }\end{array}$ & $\begin{array}{l}48.1 \\
48.1 \\
77.8\end{array}$ & $\begin{array}{l}29.6 \\
29.6 \\
37.0\end{array}$ \\
\hline 0.18 & $\begin{array}{l}\text { Max. } 4.9 \mathrm{ha} / \mathrm{au} \\
\text { Max. } 3.6 \mathrm{ha} / \mathrm{au} \\
\text { Unlimited }\end{array}$ & $\begin{array}{l}51.9 \\
51.9 \\
81.5\end{array}$ & $\begin{array}{r}3.7 \\
29.6 \\
29.6\end{array}$ \\
\hline 0.21 & $\begin{array}{l}\text { Max. } 4.9 \mathrm{ha} / \mathrm{au} \\
\text { Max. } 3.6 \mathrm{ha} / \mathrm{au} \\
\text { Unlimited }\end{array}$ & $\begin{array}{l}51.9 \\
51.9 \\
81.5\end{array}$ & $\begin{array}{r}3.7 \\
3.7 \\
29.6\end{array}$ \\
\hline
\end{tabular}

years. Averaged across the 3 heavier use factors, the probability of the annual income (net returns) falling below $\$ 27,000.00$ in at least 1 out of every 10 years was much greater for the unlimited than limited stocking tactics.

When the May use factor was changed from 0.12 to 0.15 , the probabilities of net returns falling below the threshold level in at least 1 out of 10 years was substantially reduced for both limited stocking tactics. This indicated inefficient utilization of the forage resource at the 0.12 level. Because the probability of falling below the threshold level in 1 year out of 10 remained virtually unchanged for the unlimited tactic regardless of the May use factor, a producer could utilize the forage at a greater rate in May without increasing risk. The probability of falling below the critical level generally decreased over all the stocking rate tactics as the May use factor was changed from 0.12 to 0.21 which showed that by using a flexible stocking rate to enhance harvest efficiency, the probability of low net returns decreased.

Tables 3 and 4 summarize the losses and gains to capital investment caused by cow transactions above normal culling. These transactions above normal culling indicate the investment capital

Table 3. Meam, standard deviations, and the coefficients of variation for the annual capital investment coets of cow transactions above normal culling for 3 stocking tactics and 4 use factors over the 36 year period (1950-1985).

\begin{tabular}{|c|c|c|c|c|}
\hline \multirow[t]{2}{*}{$\begin{array}{l}\text { May use } \\
\text { factor }\end{array}$} & \multirow[t]{2}{*}{ Stocking tactic } & Mean & $\begin{array}{l}\text { Standard } \\
\text { deviation }\end{array}$ & C.V. \\
\hline & & dolls & ncon & \\
\hline 0.12 & $\begin{array}{l}\text { Max. } 4.9 \mathrm{ha} / \mathrm{au} \\
\text { Max. } 3.6 \mathrm{ha} / \mathrm{au} \\
\text { Unlimited }\end{array}$ & $\begin{array}{l}-546.161 \\
-449.77 \\
1,446.22\end{array}$ & $\begin{array}{l}56,999.00 \\
78,358.28 \\
99,686.15\end{array}$ & $\begin{array}{r}-104.36 \\
-174.22 \\
68.93\end{array}$ \\
\hline 0.15 & $\begin{array}{l}\text { Max. } 4.9 \mathrm{ha} / \mathrm{au} \\
\text { Max. } 3.6 \mathrm{ha} / \mathrm{au} \\
\text { Unlimited }\end{array}$ & $\begin{array}{r}-646.07 \\
-906.26 \\
413.76\end{array}$ & $\begin{array}{r}50,645.40 \\
76,347.84 \\
109,447.45\end{array}$ & $\begin{array}{l}-78.39 \\
-84.25 \\
264.52\end{array}$ \\
\hline 0.18 & $\begin{array}{l}\text { Max. } 4.9 \text { ha/au } \\
\text { Max. } 3.6 \mathrm{ha} / \mathrm{au} \\
\text { Unlimited }\end{array}$ & $\begin{array}{r}-297.02 \\
-1,089.96 \\
153.02\end{array}$ & $\begin{array}{r}43.017 .44 \\
70,553.26 \\
111,826.60\end{array}$ & $\begin{array}{r}-144.83 \\
-64.73 \\
730.78\end{array}$ \\
\hline 0.21 & $\begin{array}{l}\text { Max. } 4.9 \mathrm{ha} / \mathrm{au} \\
\text { Max. } 3.6 \mathrm{ha} / \mathrm{au} \\
\text { Unlimited }\end{array}$ & $\begin{array}{l}-208.46 \\
-961.93 \\
1,489.28\end{array}$ & $\begin{array}{r}37,152.44 \\
63,521.07 \\
117,971.95\end{array}$ & $\begin{array}{r}-178.23 \\
-66.04 \\
79.21\end{array}$ \\
\hline
\end{tabular}

iNegative annual costs indicate that, on the average, more investment capital was received from the sale of cows than was expended to purchase cows.
Table 4. Probability that in any 10 year period accumulated cow inveatment capital will fall below zero in $1,3,5,7$, and 9 or more years for 3 stocking tactics and $4 \mathrm{May}$ use factors.

\begin{tabular}{lllllll}
\hline \hline \multirow{2}{*}{$\begin{array}{l}\text { May use } \\
\text { factor }\end{array}$} & Stocking tactic & One & Three & Five & Seven & Nine \\
\cline { 3 - 7 } & & & \multicolumn{5}{c}{ Percent } \\
\hline \multirow{4}{*}{0.12} & Max. 4.9 ha/au & 70.4 & 55.6 & 44.4 & 37.0 & 18.5 \\
& Max. 3.6 ha/au & 77.8 & 63.0 & 55.5 & 37.0 & 18.5 \\
& Unlimited & 88.8 & 66.6 & 55.5 & 37.0 & 22.2 \\
& Max. 4.9 ha/au & 85.2 & 48.1 & 37.0 & 29.6 & 18.5 \\
0.15 & Max. 3.6 ha/au & 63.0 & 55.5 & 44.4 & 37.0 & 18.5 \\
& Unlimited & 88.8 & 74.1 & 59.3 & 37.0 & 25.9 \\
& Max. 4.9 ha/au & 85.2 & 66.6 & 51.8 & 37.0 & 18.5 \\
0.18 & Max. 3.6 ha/au & 85.2 & 48.1 & 44.4 & 33.3 & 14.8 \\
& Unlimited & 92.6 & 70.4 & 51.8 & 40.7 & 25.9 \\
& Max. 4.9 ha/au & 74.0 & 66.6 & 51.8 & 40.7 & 22.2 \\
0.21 & Max. 3.6 ha/au & 85.2 & 51.8 & 37.0 & 25.9 & 14.8 \\
& Unlimited & 92.6 & 77.8 & 59.2 & 44.4 & 25.9 \\
\hline
\end{tabular}

1 Accumulated cow investment capital refers to the sum of annual receipts from sales and/or expenditures for purchases of cows over the 10-year period. When accumulated investment capital becomes negative in any given year, the total capital expended to purchase cows for that and all previous years in the period exceeds the total capital received from sales of cows. Thus, the lower the probability of accumulated investment capital becoming negative, the less likely that the rancher would have to borrow money to maintain the desired herd size.

costs associated with buying and selling cows for the breeding herd to match forage demand with available supply. The average annual cow investment costs, their associated standard deviations, and the resulting coefficients of variation are presented in Table 3. Negative annual costs indicate that, on the average, more investment capital was received from the sale of cows than was expended to purchase cows. Table 4 gives the probabilities associated with the accumulated investment capital costs being negative in at least 1,3 , 5,7 , and 9 years out of any 10 -year period.

The tactics with upper stocking rate limits had negative average annual investment capital costs across all May use factors. The unlimited tactic showed a positive average annual investment cost regardless of May use factor. This indicated that for the limit tactics there would be capital investment inflows to the ranch and for the unlimited tactic there would be investment capital outflows. The unlimited stocking tactic resulted in equal or greater probabilities that accumulated annual investment capital would be negative in at least $1,3,5,7$, and 9 out of 10 years, compared to both the limited stocking tactics regardless of the level of the May use factor.

For the use factors of 0.12 and 0.15 the $4.9 \mathrm{ha} / \mathrm{au}$ maximum tactic generally results in equal or lower probabilities that accumulated investment capital will be negative in at least $(x)$ years out of 10 , except when $(x)$ is equal to 1 and the use factor for May is 0.15 when compared to the $3.6 \mathrm{ha} / \mathrm{au}$ tactic. Further comparison of the limited tactics indicate that the $3.6 \mathrm{ha} /$ au tactic results in equal or lower probabilities that accumulated investment capital will be negative in at least $(x)$ years out of 10 when the use factor is 0.18 and 0.21 , the only exception being when (x) equal 1 and the use factor equals 0.21 .

\section{Conclusions}

For the management regimes presented in this study, average annual net returns increased as the maximum stocking rate allowed increased; however, the variation in annual net returns also increased. Based on the annual net returns estimates, an argument favoring the use of a maximum stocking of $3.6 \mathrm{ha} / \mathrm{au}$ can be developed. The argument is based on the tactic's average net 
returns and relative variation of returns. Also, in all but 1 instance ( 0.18 use factor) this tactic has the lowest probability of net returns falling below the critical level in 1 or 3 years out of 10 .

Considering the average annual capital investment changes associated with the $\mathbf{2}$ tactics where stocking limits are set, the average decrease in annual capital investment was greater under 3 of the 4 use factors when the $3.6 \mathrm{ha} / \mathrm{au}$ tactic was utilized. On the other hand, the unlimited tactic caused average annual investment costs to increase as the use factor increased.

Under the environment simulated, the model does not clearly identify a unique optimal tactic. It does present information on the net returns and capital requirements which might be expected under different tactics and forage use levels while incorporating forage changes and price movements. The model can be modified to incorporate more decision times or changes in the decision, different rates, changes in livestock management and changes in annual forage production. These modifications would need to be incorporated if the model were to be used in other regions since the model was site specific. The model could be improved by incorporating the tax implications for the different capital investment requirements associated with the alternative tactics. As presented, however, the model does provide important aids in the development of more refined decision making guidelines and tools for intensively managed grazing systems. Refinement of decision tools in this area will hopefully lead to software decision aids which will be available to the decision maker on the ranch. A manager will then have the tools necessary to estimate the economic consequences of his or her actions before making stocking rate adjustments.

\section{Literature Cited}

Conner, J.R., and P.J. Chamberinin. 1985. Profitability analysis of ranch investments, p. 107-117. In: L.D. White and T.R. Troxel (eds), Proc. 1986 Int. Ranchers Roundup. Texas Agr. Res. and Ext. Cent., Uvalde.
Halter, A.N., and G.W. Dean. 1965. Use of simulation in evaluating management policies under uncertainty: application to a large scale ranch. J. Farm Econ. 47:557-573.

Heltschmidt, R.K., S.L. Dowher, D.L. Price, and R.A. Gordon. 1985. Response of vegetation to livestock grazing at the Texas experimental range. Texas Agr. Exp. Sta. Bull. 1515.

Heitschmidt, R.K. 1986. Vegetation and cow calf response to rotational grazing at the Texas Experimental Ranch. p. 207-211. In: P.J. Joss P.W. Lynch, and O.B. Williams (ed.). Rangelands: a resource under siege. Proc. Second Int. Rangeland Cong. Australian Acad. Sci., Conaerra.

Heitschmidt, R.K., S.L. Dowhower, and J.W. Walker. 1987a. 14-vs. 42paddock rotational grazing: aboveground biomass dynamics, forage production and harvest efficiency. J. Range Manage. 40:216-223.

Heitschmidt, R.K., S.L. Dowhower, and J.W. Walker. 1987b. 14 vs. 42 paddock rotational grazing: forage quality. J. Range Manage. 40:315-317.

Heitschmidt, R.K., S.L. Dowhower, and J.W. Walker. 1987c. Some èffects of a rotational grazing treatment on quantity and quality of available forage and amount of ground litter. J. Range Manage. 40:318-321.

Heitachmidt, R.K., J.R. Conner, and W.E. Pinchak. 1987. Grazing management to meet goals, p. 61-70. In: L.D. White, T.R. Troxel and J.M. Payne (eds), Proc. 1987 Int. Ranchers Roundup. Texas Agr. Res. and Ext. Cent., Uvalde.

Olson, Philip D. 1984. Influence of stocking rate on nutritive intake of steers grazing in a short duration grazing system. Ph.D. Diss. Texas A\&M Univ., College Station.

Riecher, R.K. 1986. An economic analysis of alternative stocking rate adjustment strategies for short duration grazing systems in the Texas Rolling Plains. M.S. Thesis. Texas A\&M Univ., College Station.

Society for Range Manazement. 1974 A glossary of terms used in range management. 2nd Edition. Soc. Range Manage. Denver, Colo.

VanTasaell, L.W., R.K. Heitschmidt, and J.R. Conner. 1987. Modeling variation in range calf growth under conditions of environmental uncertainty. J. Range Manage. 40:310-314.

Whitson, R.B. 1974. Evaluating the relationship between income and uncertainty for a Texas ranch organization. Ph.D. Diss. Texas A\&M Univ. College Station. 